\title{
Temperature effects on growth, colony development and carbon partitioning in three Phaeocystis species
}

\author{
Xiaodong Wang ${ }^{1, *}$, Kam W. Tang ${ }^{2}$, Yan Wang ${ }^{3}$, Walker O. Smith, Jr. ${ }^{2}$ \\ ${ }^{1}$ College of Environmental Science and Engineering, Ocean University of China, Qingdao 266100, China \\ ${ }^{2}$ Virginia Institute of Marine Science, College of William and Mary, Gloucester Point, Virginia 23062, USA \\ ${ }^{3}$ Research Center for Harmful Algae and Aquatic Environment, Jinan University, Guangzhou 510632, China
}

\begin{abstract}
Phaeocystis is an ecologically important marine phytoplankton genus that is globally distributed. We examined the effects of temperature on the 3 most common species: P. globosa, $P$. antarctica, and $P$. pouchetii, which grew at $16-32,0-6$, and $4-8^{\circ} \mathrm{C}$, respectively. $P$. pouchetii did not form colonies; P. globosa formed colonies at 16,20 , and $24^{\circ} \mathrm{C}$, and $P$. antarctica colonies were observed at all temperatures. More cells were partitioned into the colonial form at lower temperatures than at higher temperatures for P. globosa and P. antarctica. P. globosa colony size decreased with temperature, whereas $P$. antarctica colony size showed no distinct response to temperature. Numbers of cells per unit of colony surface area of $P$. globosa and $P$. antarctica were lowest at temperatures where highest growth rates and colonial abundances were observed; more organic carbon was partitioned into solitary cell biomass at higher temperatures, whereas the carbon concentration of colonies was not affected by temperature. Maximum quantum yield of $P$. antarctica and $P$. globosa exhibited subtle responses to temperature, whereas that of $P$. pouchetii was relatively invariant within the growth temperature range. Future changes in sea surface temperature may dramatically alter the ecology and biogeochemical cycles of systems dominated by Phaeocystis spp. and result in further degradation, via oxygen depletion and altered food web structure.
\end{abstract}

KEY WORDS: Phaeocystis spp. · Temperature $\cdot$ Colony formation · Carbon partitioning

\section{INTRODUCTION}

The genus Phaeocystis (Prymnesiophyceae) is one of the most widespread marine phytoplankton taxa, and plays a significant role in global carbon and sulfur cycles, food web structure, and climate regulation (Lancelot et al. 1998, Schoemann et al. 2005). It has the ability to form massive blooms that have substantial impacts on coastal systems, and it has a complex polymorphic life cycle that involves both colonial and solitary forms. The solitary cells, either flagellated or nonflagellated, are typically 3 to $9 \mu \mathrm{m}$ in diameter. The colonial stage, with cells embedded in a polysaccharide gel matrix, may reach up to $3 \mathrm{~cm}$ in diameter (Rousseau et al. 1994, Chen et al. 2002). The organic matrix may provide an energy or nutrient source during periods of darkness or heterotrophic growth by the cells (Lancelot \& Mathot 1985, Schoemann et al. 2001), but also represents a considerable carbon and energy demand for the individual cells. The success of Phaeocystis is often attributed to its ability to form colonies, which potentially provide protection for the colonial cells against grazers, viruses, and bacteria (Hamm et al. 1999, Jakobsen \& Tang 2002, Brussaard et al. 2005). Of the 6 described Phaeocystis species, 3 are widespread and regularly develop blooms in colonial form: P. globosa, P. pouchetii, and P. antarctica (Medlin \& Zingone 2007).

Phaeocystis is also a harmful algal genus in coastal waters (Lancelot et al. 1998). It forms dense blooms in the eutrophic North Sea (Lancelot et al. 1987), although observations and continuous plankton records show that it has occurred in the North Atlantic since the early 19th century (Cadée \& Hege- 
man 2002, Gieskes et al. 2007). The blooms reach a high biomass and generate both hypoxic zones at depth (Peperzak \& Poelman 2008) and dense organic films on beaches (Lancelot et al. 1987). They have both an ecological impact on the local food web and a negative economic influence on tourism. Dense blooms have also been observed off the coasts of southeast China (Qi et al. 2004), Vietnam (Tang et al. 2004), and Norway (Larsen et al. 2004). The clones isolated from Chinese and Norwegian waters have hemolytic properties as well (Shen et al. 2004, van Rijssel et al. 2007).

Different Phaeocystis species occur over different temperature ranges in the ocean (Schoemann et al. 2005). For example, $P$. pouchetii grows at temperatures below $5^{\circ} \mathrm{C}$, and the reported optimal temperature range for North Sea P. globosa is 15 to $20^{\circ} \mathrm{C}$ (Schoemann et al. 2005). The temperature range of $P$. pouchetii overlaps with that of P. globosa (Baumann et al. 1994), such that $P$. pouchetii is also found in warm waters (Philippart et al. 2000). P. antarctica is confined to low temperatures and ceases to grow above $7^{\circ} \mathrm{C}$ (Buma et al. 1991). In general, P. globosa blooms in temperate and tropical regions, $P$. pouchetii in subarctic waters, and $P$. antarctica in the Southern Ocean (Schoemann et al. 2005). Temperature affects physiological responses of Phaeocystis in addition to altering growth. For example, $P$. antarctica releases more dimethyl sulfide at lower temperatures (Baumann et al. 1994). Furthermore, the cellular carbon content of $P$. pouchetii is greater at low than at high temperatures (Jahnke 1989), and solitary cells of $P$. pouchetii have higher photosynthetic and excretion rates than colonial cells at low temperatures (Verity et al. 1991). The carbon to chlorophyll a (chl a) ratio and cell size of $P$. pouchetii solitary cells vary inversely with temperature, whereas colonial photosynthesis is positively related to temperature (Verity et al. 1991). When subjected to a rapid temperature reduction, colonial cells of $P$. pouchetii develop flagella, become motile, and emigrate from the colonies (Verity et al. 1988).

While these individual studies collectively suggest that temperature plays a key role in Phaeocystis biology and ecology, the different strains and experimental designs used by the investigators make it difficult to compare and predict the response of different Phaeocystis species to temperature. In addition, because of the complex life history of the genus, it remains uncertain how temperature might affect the relative abundances of solitary and colonial cells, as well as its influence on photosynthetic capacity and carbon partitioning. These questions are particularly relevant to understanding how Phaeocystis may affect the marine food web and biogeochemistry in future climate scenarios.
The objective of this study was to investigate the growth and biological responses of the 3 major Phaeocystis species ( $P$. globosa, P. pouchetii, and P. antarctica) to temperature under defined experimental conditions. Colonial and solitary cell abundances, colony abundance and size, quantum yield, and particulate organic carbon contents of the 3 species grown under a range of temperatures were determined. We hypothesized that temperature would significantly influence the growth of cells, colony formation, photosynthesis, and the partitioning of organic carbon among solitary cells, colonial cells, and the colonial matrix.

\section{MATERIALS AND METHODS}

Stock maintenance. Phaeocystis globosa (CCMP 1528; originally isolated from the South Pacific) and P. antarctica (CCMP 1871; originally isolated from the Bellingshausen Sea) were obtained from the Culture Collection at Bigelow Laboratory (Maine, USA). A culture of $P$. pouchetii (AJ 01; originally isolated from the Norwegian coast) was provided by J. Nejstgaard (University of Bergen, Norway). These strains were used in previous studies of Phaeocystis biology and ecology (Brussaard et al. 2001, Tang 2003, Elliott et al. 2008, Wang et al. 2010). P. globosa CCMP 1528 and P. antarctica CCMP 1871 regularly form colonies, while $P$. pouchetii only grows as solitary cells in the laboratory. The 3 species were maintained at 20,0 , and $8^{\circ} \mathrm{C}$, respectively, in $f / 2$ medium (Guillard \& Ryther 1962) with a salinity of 32 under an irradiance of $100 \mu \mathrm{mol}$ photons $\mathrm{m}^{-2} \mathrm{~s}^{-1}$ on a 12:12 h light:dark cycle. The stocks were maintained in exponential growth by regular dilutions with fresh medium.

Experimental cultures. We first grew the 3 Phaeocystis species under defined conditions to establish growth curves and determine when biomass became maximal. Solitary Phaeocystis cells were collected by passing the stocks twice through a $10 \mu \mathrm{m}$ nylon sieve under gravity, and were placed in triplicate $1 \mathrm{l}$ flasks at an initial cell density of $10^{4}$ cells ml $\mathrm{ml}^{-1}\left(500 \mathrm{ml} \mathrm{flask}^{-1}\right)$. All cultures were grown in growth chambers using $f / 2$ medium with a salinity of 32 under an irradiance of $350 \mu \mathrm{mol}$ photons $\mathrm{m}^{-2} \mathrm{~s}^{-1}$, but at different temperatures $\left( \pm 1^{\circ} \mathrm{C}\right)$ : P. globosa at $20^{\circ} \mathrm{C}, P$. antarctica at $0^{\circ} \mathrm{C}$, and $P$. pouchetii at $8^{\circ} \mathrm{C}$ (Table 1). During incubations, the flasks were shaken gently by hand daily to avoid excessive cell settlement. In vivo chl a was measured daily in triplicate flasks at each temperature to establish growth curves from lag through senescent phases, and the maximum instantaneous growth rates were determined from the inflection point of the growth curves. Next, 3 sets of new flasks were initiated under the same conditions using the previous cultures as 
Table 1. Phaeocystis spp. Temperatures and maximum growth rates (mean $\pm \mathrm{SD}_{i} \mathrm{n}=3$ ). Starting temperatures for each species are shown in bold. Temperature was altered by 2 to $4^{\circ} \mathrm{C}$ between experiments. NG: no growth

\begin{tabular}{|lcc|}
\hline & $\begin{array}{c}\text { Temperature } \\
\left({ }^{\circ} \mathrm{C}\right)\end{array}$ & $\begin{array}{c}\text { Maximum growth } \\
\text { rate }\left(\mathrm{d}^{-1}\right)\end{array}$ \\
\hline P. globosa & 32 & $0.54 \pm 0.00$ \\
& 28 & $0.59 \pm 0.04$ \\
& 24 & $0.50 \pm 0.08$ \\
& $\mathbf{2 0}$ & $1.10 \pm 0.38$ \\
16 & $0.19 \pm 0.11$ \\
& 12 & $\mathrm{NG}$ \\
& 8 & $\mathrm{NG}$ \\
& & \\
& 8 & $\mathrm{NG}$ \\
& 6 & $0.12 \pm 0.03$ \\
& 4 & $0.35 \pm 0.02$ \\
& 2 & $0.17 \pm 0.04$ \\
& $0.16 \pm 0.00$ \\
& $\mathbf{0}$ pouchetii & $\mathrm{NG}$ \\
& -2 & \\
& 16 & $\mathrm{NG}$ \\
& 12 & $\mathrm{NG}$ \\
& $\mathbf{8}$ & $0.50 \pm 0.06$ \\
6 & $0.19 \pm 0.01$ \\
4 & $0.23 \pm 0.01$ \\
2 & $\mathrm{NG}$ \\
0 & $\mathrm{NG}$ \\
& -2 & $\mathrm{NG}$ \\
\hline
\end{tabular}

inocula, and the cultures were grown to maximum biomass based on the previously determined growth curves. They were then harvested for the determination of biomass and photosynthetic parameters. Once an experiment for a specific temperature was completed, remaining aliquots were inoculated with fresh medium and transferred to a different temperature. The temperature was altered by 2 to $4^{\circ} \mathrm{C}$ between experiments for a number of generations, allowing the phytoplankton to gradually acclimate to the new temperature (Table 1). Once the cultures resumed active growth at the new temperature, aliquots were taken to initiate new growth curves and experiments.

Microscopy and chlorophyll measurements. Samples for microscopic enumeration of cell and colony abundances were preserved in Lugol's solution. Solitary cell concentrations were measured using Sedgwick-Rafter chambers (Tang 2003). Colony concentration, colony size, and cells per colony were enumerated in 24 -well multi-plates using a Nikon inverted microscope with a calibrated micro-ruler (Tang 2003). Aliquots of known volume were filtered through Whatman GF/F filters to obtain total chl $a$, and through $20 \mu \mathrm{m}$ polycarbonate membranes (Poretics) to obtain the $>20 \mu \mathrm{m}$ fraction, which was taken as representative of colonial chlorophyll (Tang et al. 2008). All chl a samples were extracted in darkness at $0^{\circ} \mathrm{C}$ for $24 \mathrm{~h} \mathrm{in} 7 \mathrm{ml}$ of $90 \%$ acetone; fluorescence of extracted chl a was measured on a TD-700 fluorometer (Turner Designs) before and after acidification (Parsons et al. 1984). The fluorometer was calibrated using commercially prepared chl a (Turner Designs, purity 98.0\%).

Maximum quantum yield of PSII $\left(F_{\mathrm{v}} / F_{\mathrm{m}}\right)$. To assess the response of potential photosynthesis to temperature, we measured the potential quantum yield using fluorescence techniques. Phaeocystis cultures were dark-adapted for $30 \mathrm{~min}$, after which the minimal $\left(F_{0}\right)$ and maximal $\left(F_{\mathrm{m}}\right)$ fluorescence were measured before and after addition of DCMU solution (final concentration of $10^{-5} \mathrm{M}$ ) on a TD-700 fluorometer. Maximum quantum yield of PSII was calculated as: $F_{\mathrm{v}} / F_{\mathrm{m}}=$ $\left(F_{\mathrm{m}}-F_{0}\right) / F_{\mathrm{m}}$, where $F_{\mathrm{v}}$ is variable fluorescence (Vincent 1980).

Particulate organic carbon. All glassware, vials, and GF/F filters used to measure particulate organic carbon (POC) were pre-combusted $\left(4 \mathrm{~h}, 450^{\circ} \mathrm{C}\right)$. An aliquot of 20 to $40 \mathrm{ml}$ from each experimental flask was filtered through GF/F filters to collect the total POC $\left(\mathrm{POC}_{\mathrm{T} ;} \mu \mathrm{g} \mathrm{ml}^{-1}\right)$. To obtain the solitary cell POC fraction $\left(\mathrm{POC}_{\mathrm{SC}} \mu \mathrm{g} \mathrm{ml}^{-1}\right)$, solitary cells were collected by filtering $20 \mathrm{ml}$ aliquot through a $10 \mu \mathrm{m}$ sieve under gravity and then onto a GF/F filter. Based on known solitary cell concentration (see above), we estimated the carbon content of individual solitary cells. An additional $50 \mathrm{ml}$ aliquot of a mixture of colonies and solitary cells was vortexed for 5 to $10 \mathrm{~min}$; microscopic examination confirmed that this procedure released some (but not all) of the colonial cells while keeping the organic gel matrix relatively intact. The vortexed sample was passed through a $10 \mu \mathrm{m}$ sieve to collect all single forms (that is, solitary + released colonial cells) in the filtrate. The abundance of released colonial cells was then obtained by subtracting the corresponding number of solitary cells based on the independently determined solitary cell abundance in the same aliquot volume before vortexing. The filtrate (solitary + released colonial cells) was filtered onto GF/F filter to obtain $\mathrm{POC}$, from which the corresponding amount of solitary cell carbon was subtracted to calculate POC per colonial cell. This value was then scaled up to the total colonial cell abundance in the experimental flask (see above) to obtain the colonial cell POC fraction $\left(\mathrm{POC}_{\mathrm{CC} i} \mu \mathrm{g} \mathrm{ml}^{-1}\right)$. The POC fraction from matrix material was then calculated as $\mathrm{POC}_{\mathrm{M}}\left(\mu \mathrm{g} \mathrm{ml}{ }^{-1}\right)=\mathrm{POC}_{\mathrm{T}}-$ $\mathrm{POC}_{\mathrm{SC}}-\mathrm{POC}_{\mathrm{CC}}$.

All samples for POC were rinsed with ca. $5 \mathrm{ml}$ of $0.01 \mathrm{~N} \mathrm{HCl}$ in seawater to remove any inorganic carbon adsorbed to the filter (Gardner et al. 2000), and then dried in glass vials at $60^{\circ} \mathrm{C}$. Dried filters were analyzed for carbon by flash combustion using a Carlo-Erba Model EA 1108 elemental analyzer. Similar amounts of culturing medium were filtered and processed in the same manner as blanks to correct the sample carbon values. 

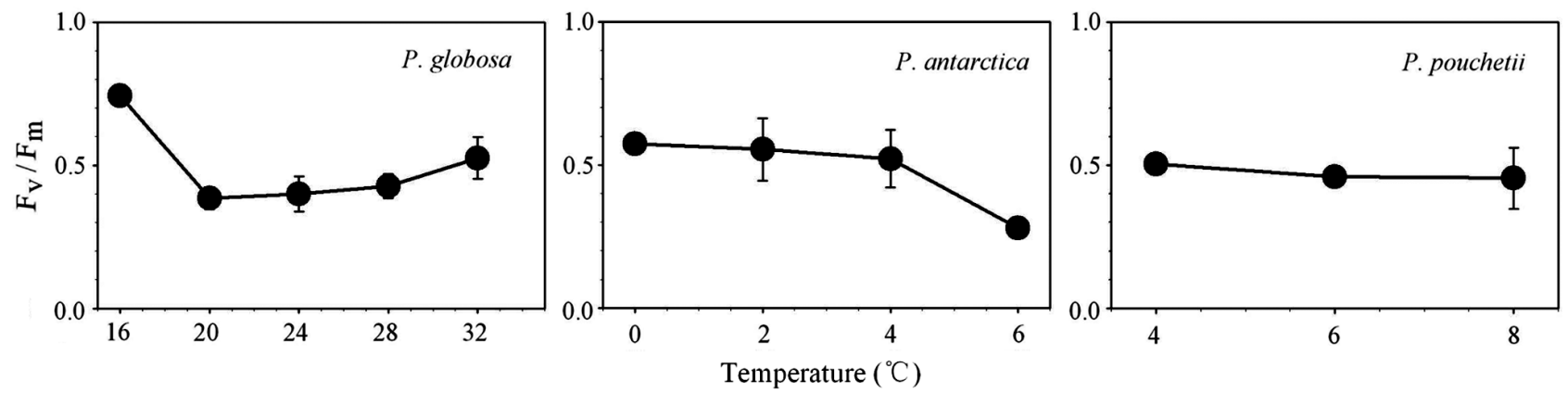

Fig. 1. Phaeocystis spp. Quantum yields $\left(F_{\mathrm{v}} / F_{\mathrm{m}}\right.$ mean $\pm \mathrm{SD} ; \mathrm{n}=3$; see 'Materials and methods' for definitions of terms $)$ at different temperatures

Statistical analysis. SigmaStat (v. 3.50 SPSS) and Minitab (v. 15) were used for statistical analyses. Statistical comparisons of the effects of temperature on growth, $F_{\mathrm{v}} / F_{\mathrm{m}}$, cell abundance, partitioning of cells, chlorophyll, and POC were made by 1-way ANOVA. Prior to ANOVA, percentage data were normalized by an arcsine transformation (Zar 1984). In cases where data did not satisfy the criteria for parametric tests, 1way ANOVA on ranks was used. Post hoc comparison following ANOVA was done by Dunn's method, the Holm-Sidak method, or a Tukey test. Linear regressions were fit to $\log$ cells colony ${ }^{-1}$ versus log colony diameter, and comparison of the slopes of regressions between temperatures was done by 1-way analysis of covariance (ANCOVA). Correlation between different parameters was tested by a Pearson correlation test. The significance level for all statistical tests was $a$ priori set at a critical p value of 0.05 .

\section{RESULTS}

\section{Growth and maximum quantum yield}

The temperature ranges over which Phaeocystis globosa, $P$. antarctica, and $P$. pouchetii grew were 16 to 32,0 to 6 , and 4 to $8^{\circ} \mathrm{C}$, respectively (Table 1 ). Within these temperatures, the maximum growth rates based on in vivo chlorophyll measurements were observed at 20,4 , and $8^{\circ} \mathrm{C}$, respectively, for the 3 species (Table 1 ).
The growth of $P$. globosa decreased significantly from 20 to $16^{\circ} \mathrm{C}(\mathrm{p}<0.05)$; however, there was no significant difference in growth among 24,28 , and $32^{\circ} \mathrm{C}$, although all 3 were less than the maximum observed at $20^{\circ} \mathrm{C}$. The growth rate of $P$. antarctica increased significantly from 0 to $4^{\circ} \mathrm{C}(\mathrm{p}<0.05)$, and then decreased at $6^{\circ} \mathrm{C}$. Similarly, the growth of $P$. pouchetii was also affected by temperature $(p<0.01)$, and reached a maximum at $8^{\circ} \mathrm{C}$.

The differences in $F_{\mathrm{v}} / F_{\mathrm{m}}$ among temperatures were not significant for Phaeocystis pouchetii $(\mathrm{p}>0.05)$ and ranged from 0.46 to 0.51 (Fig. 1). $F_{\mathrm{v}} / F_{\mathrm{m}}$ of $P$. globosa was markedly higher at $16^{\circ} \mathrm{C}$, but decreased at $20^{\circ} \mathrm{C}$ before increasing slightly at $32^{\circ} \mathrm{C}(\mathrm{p}<0.001) . F_{\mathrm{v}} / F_{\mathrm{m}}$ of $P$. antarctica was significantly lower at $6^{\circ} \mathrm{C}$ than at other temperatures ( $\mathrm{p}<0.05$; Fig. 1).

\section{Colony and cell abundances}

Unlike in nature, colony development did not occur in our Phaeocystis pouchetii culture. P. globosa formed colonies at 16,20 , and $24^{\circ} \mathrm{C}$, whereas $P$. antarctica colonies were observed in all 4 temperature treatments (Fig. 2). Colony abundance was highest at $20^{\circ} \mathrm{C}$ for $P$. globosa, and at $4^{\circ} \mathrm{C}$ for $P$. antarctica. Solitary cell abundance of $P$. globosa differed significantly between temperatures ( $\mathrm{p}<0.01$ ), and was highest at $28^{\circ} \mathrm{C}$ (Fig. 3). The solitary cell abundances of $P$. antarctica and $P$. pouchetii were also affected by temperature $(\mathrm{p}<0.05)$.

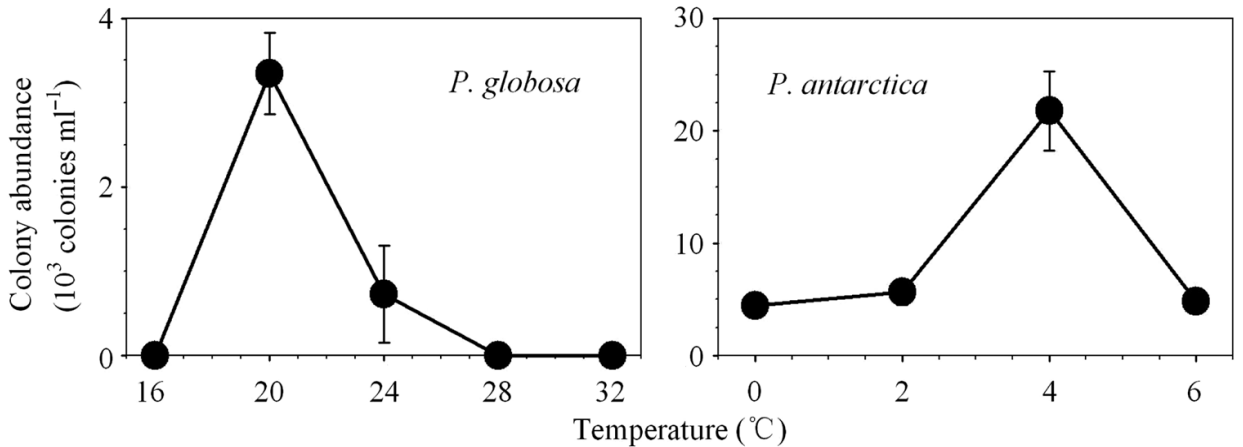

Fig. 2. Phaeocystis spp. Colony abundances (mean $\pm \mathrm{SD} ; \mathrm{n}=3$ ) at different temperatures 

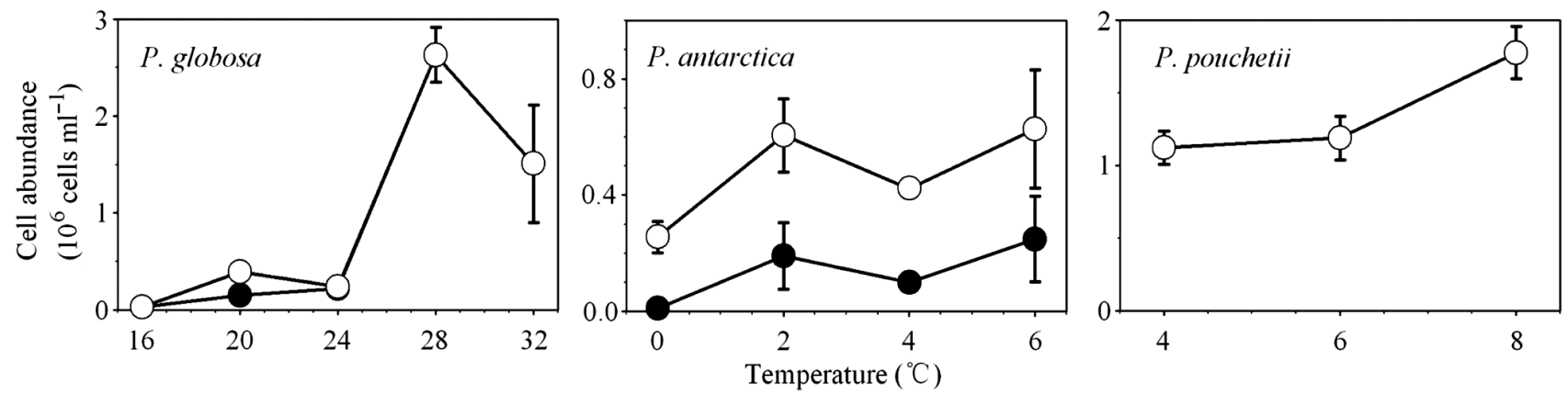

Fig. 3. Phaeocystis spp. Solitary cell (solid circles) and total cell (open circles) abundance at different temperatures (mean $\pm \mathrm{SD}$; $\mathrm{n}=3)$

Highest solitary cell concentration was at $6^{\circ} \mathrm{C}$ for $P$. antarctica and at $8^{\circ} \mathrm{C}$ for $P$. pouchetii. The total cell abundances (solitary + colonial) of P. globosa at 16, 20, and $24^{\circ} \mathrm{C}$ were far lower than the total cell abundances at higher temperatures ( $<<0.01$; Fig. 3). Unlike P. globosa, the total cell abundance of $P$. antarctica was not affected by temperature $(\mathrm{p}>0.05)$.

\section{Partitioning of cells and chlorophyll}

Temperature strongly influenced the partitioning of cells between solitary and colonial forms (Fig. 4). Phaeocystis globosa existed exclusively as solitary cells at 28 and $32^{\circ} \mathrm{C}$, and $<10 \%$ of the total cells were in colonial form at 16 and $24^{\circ} \mathrm{C}$. However, colonial cells contributed $>60 \%$ to the total P. globosa cells at $20^{\circ} \mathrm{C}$ ( $p<0.001$; Fig. 4A). For P. antarctica, the colonial form was most dominant at $0^{\circ} \mathrm{C}$, accounting for $>95 \%$ of the total cells, but this percentage decreased at the higher temperatures, so that slightly over $60 \%$ of the cells were in colonial form at $6^{\circ} \mathrm{C}(\mathrm{p}<0.05$; Fig. 4B).

Size-fractioned chlorophyll was also significantly different among temperatures. The proportion of the $>20$ $\mu \mathrm{m}$ chlorophyll fraction in Phaeocystis globosa was highest at $20^{\circ} \mathrm{C}(\mathrm{p}<0.01)$, contributing $>55 \%$ to the total chlorophyll (Fig. 4C). This size fraction accounted for $51 \%$ of the total chlorophyll in $P$. antarctica at $0^{\circ} \mathrm{C}$, and the percentage decreased to a minimum of $8 \%$ at $4^{\circ} \mathrm{C}$ (Fig. 4D). Because some small colonies could have passed through the $20 \mu \mathrm{m}$ membrane filters, it was expected that the $>20 \mu \mathrm{m}$ chlorophyll size fraction
Fig. 4. Phaeocystis spp. Percentages of colonial cells to total cells for (A) P. globosa and (B) $P$. antarctica, and percentages of $>20 \mu \mathrm{m}$ chlorophyll to total chlorophyll for (C) P. globosa and (D) $P$. antarctica (mean $\pm \mathrm{SD}$; $\mathrm{n}=3$ )
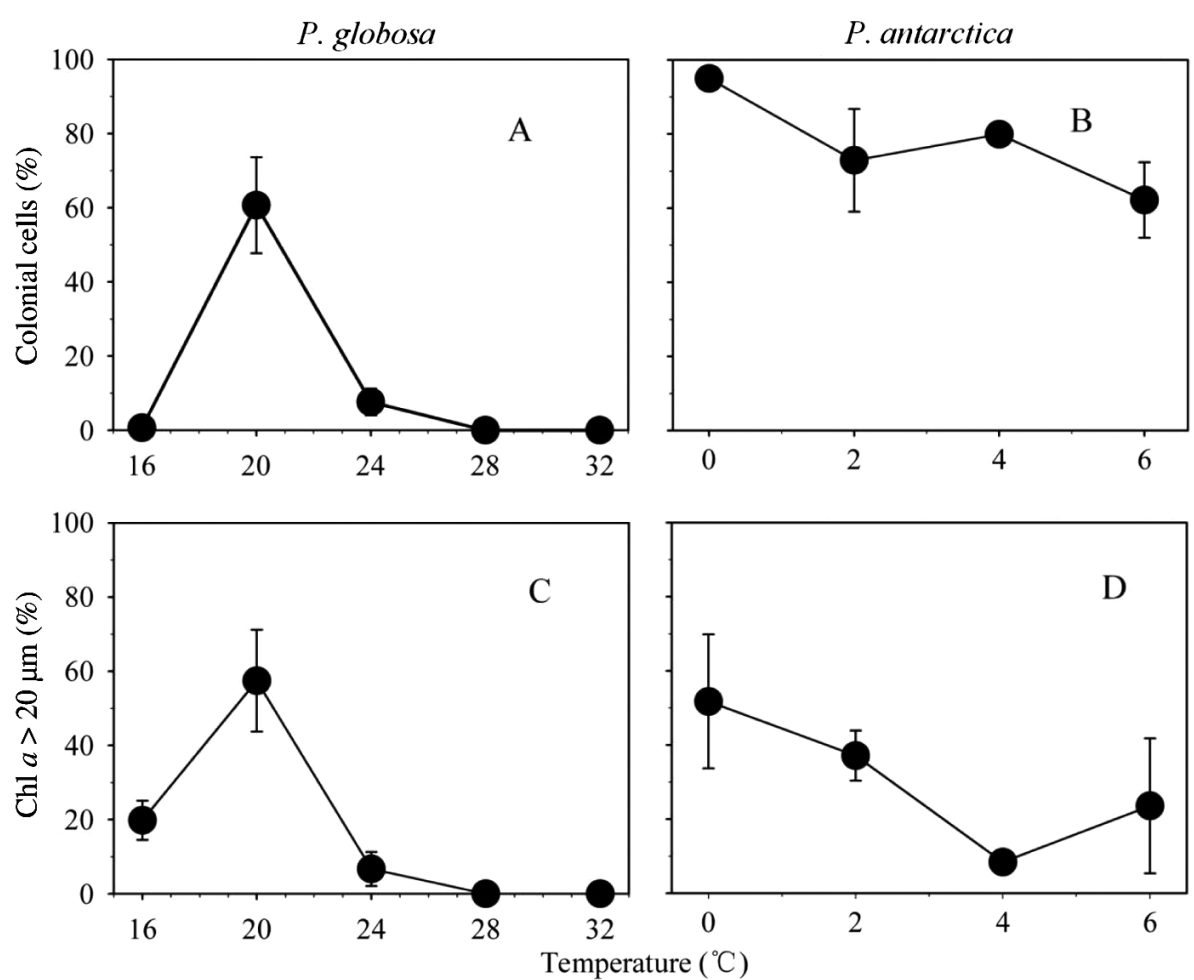

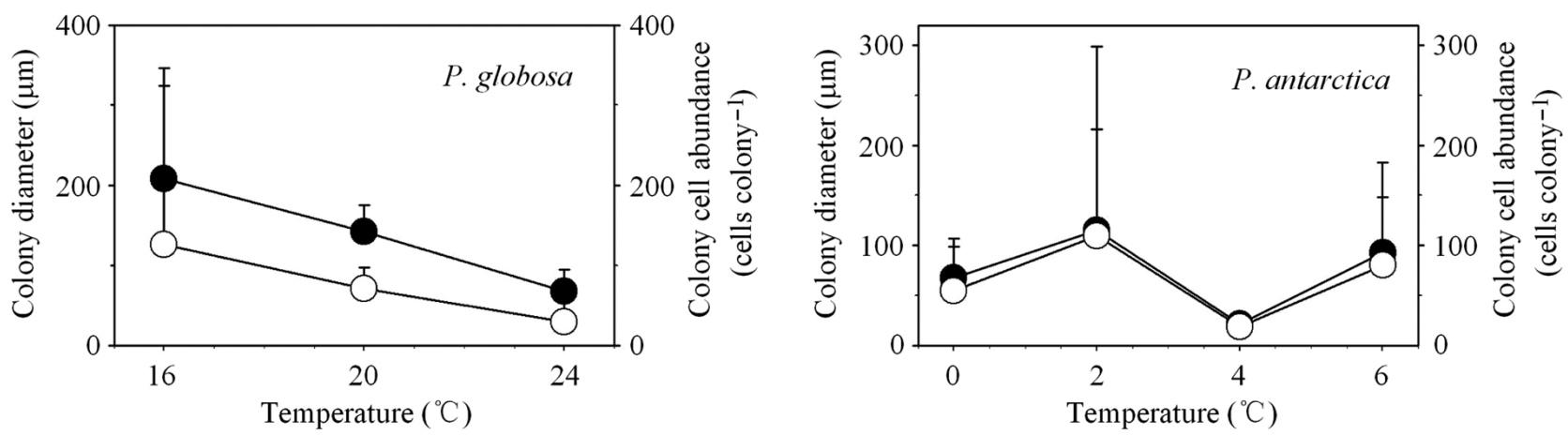

Fig. 5. Phaeocystis spp. Colony diameters (solid circles) and colonial cell abundances (open circles) of $P$. globosa and $P$. antarctica at different temperatures (mean $+\mathrm{SD}_{i} \mathrm{n}=3$ )

underestimated colony abundances. Nevertheless, the trend of chlorophyll size distribution was significantly correlated to the distribution of cell types $(p<0.001)$, with the highest percentages of $>20 \mu \mathrm{m}$ chlorophyll coinciding with the highest colonial cell percentages.

\section{Colony morphology}

Colony diameters of Phaeocystis globosa were inversely correlated to temperature $(\mathrm{p}<0.01)$, and decreased from an average of $208 \mu \mathrm{m}$ at $16^{\circ} \mathrm{C}$ to $67 \mu \mathrm{m}$ at $24^{\circ} \mathrm{C}$ (Fig. 5A). The response of $P$. antarctica colony size to temperature showed a different trend (Fig. 5B): colony diameter was smallest at $4^{\circ} \mathrm{C}$, and largest at 2 and $6^{\circ} \mathrm{C}(\mathrm{p}<0.001)$. In all cases where colonies developed, there was a significant linear log-log relationship between the number of cells colony ${ }^{-1}$ and colony diameter $(p<0.001)$ with a slope $<2$, indicating that the number of cells per unit of colony surface area decreased as the colonies increased in size (Fig. 6). For P. globosa, the slope of the regression was significantly smaller at $20^{\circ} \mathrm{C}(1.28)$ than at $16(1.65)$ and $24^{\circ} \mathrm{C}(1.64$; $\mathrm{p}<0.01)$. Thus, colonies at 16 and $24^{\circ} \mathrm{C}$ had more cells per unit of colony surface area than at $20^{\circ} \mathrm{C}$. Temperature also affected cell distribution in $P$. antarctica colonies, and the number of cells per unit of colony surface area decreased at $4^{\circ} \mathrm{C}$ relative to other temperatures $(\mathrm{p}<0.01)$.

\section{Partitioning of POC}

The concentrations of both total carbon and solitary cell carbon were higher at higher temperatures for all 3 species. For example, the total carbon and single cell carbon levels in Phaeocystis globosa were lower at 16, 20 , and $24^{\circ} \mathrm{C}$ than at 28 and $32^{\circ} \mathrm{C}(\mathrm{p}<0.05)$. For $P$. antarctica, total carbon and solitary cell carbon concentration at $0^{\circ} \mathrm{C}$ were lower than at 2,4 , and $6^{\circ} \mathrm{C}$. The carbon concentration of $P$. pouchetii also increased with temperature $(\mathrm{p}<0.001)$. In all cases, the differences in colonial cell and matrix carbon concentrations between temperatures were not significant ( $p>0.05)$, suggesting that temperature did not affect the colonies' carbon concentration.

Temperature affected the partitioning of POC in Phaeocystis antarctica and P. globosa $(\mathrm{p}<0.05$; Table 2$)$. Except for $P$. globosa at $16^{\circ} \mathrm{C}$, the percentages of solitary cell carbon were higher at higher temperatures for both species. For example, the percentage of solitary cell carbon of $P$. antarctica increased from $1.9 \%$ at $0^{\circ} \mathrm{C}$ to $68 \%$ at $6^{\circ} \mathrm{C}(\mathrm{p}<0.01)$. The percentages of colonial cell carbon and matrix carbon in $P$. antarctica and $P$. globosa were also affected by temperature $(\mathrm{p}<0.01$; Table 2).

\section{DISCUSSION}

\section{Global distribution}

The objective of this study was to understand how changes in temperature might influence the growth of Phaeocystis, especially in view of the current and anticipated warming of the world's oceans. The 3 species of Phaeocystis exhibited very different growth responses to temperature. In our study, P. globosa grew at $32^{\circ} \mathrm{C}$, which is higher than the previously reported maximum growth temperature $\left(30^{\circ} \mathrm{C}\right.$; Schoemann et al. 2005). Blooms of P. globosa occur in coastal waters of the South China Sea, where colonies up to $3 \mathrm{~cm}$ in size were reported in waters with temperatures of $30^{\circ} \mathrm{C}$ (Shen et al. 2004). Our clone was originally isolated from the tropical South Pacific, so that its ability to grow at high temperatures may reflect its origin. Peperzak (2003) reported that P. globosa derived from the North Sea ceased to grow when temperature increased from 22 to $26^{\circ} \mathrm{C}$. Its temperature range was similar to that of the isolate we used, but the absolute 
Fig. 6. Phaeocystis spp. Relationship between cell abundance per colony and colony diameter of $P$. globosa (left) and $P$. antarctica (right) at different temperatures. Solid lines are linear regressions, and dotted lines are the $95 \%$ confidence intervals. n: number of colonies measured
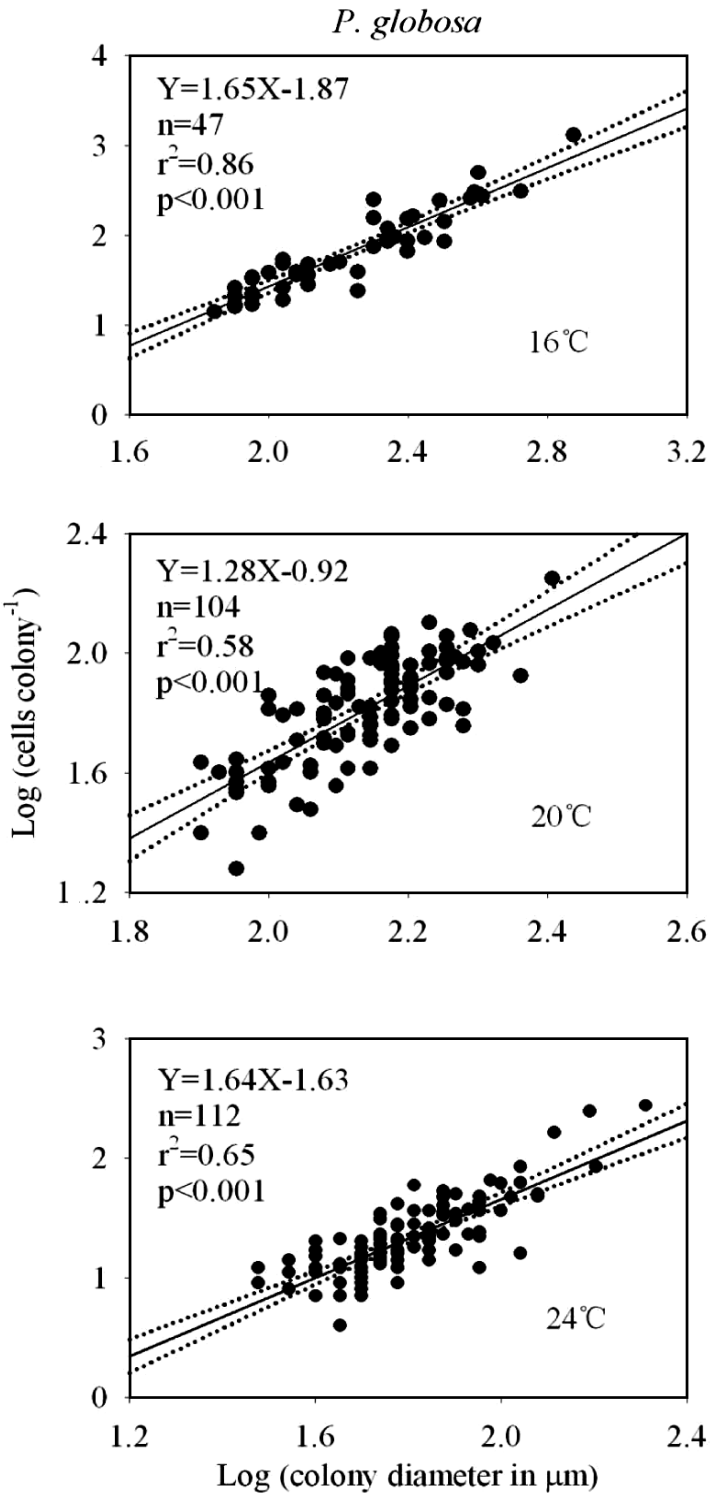

P. antarctica
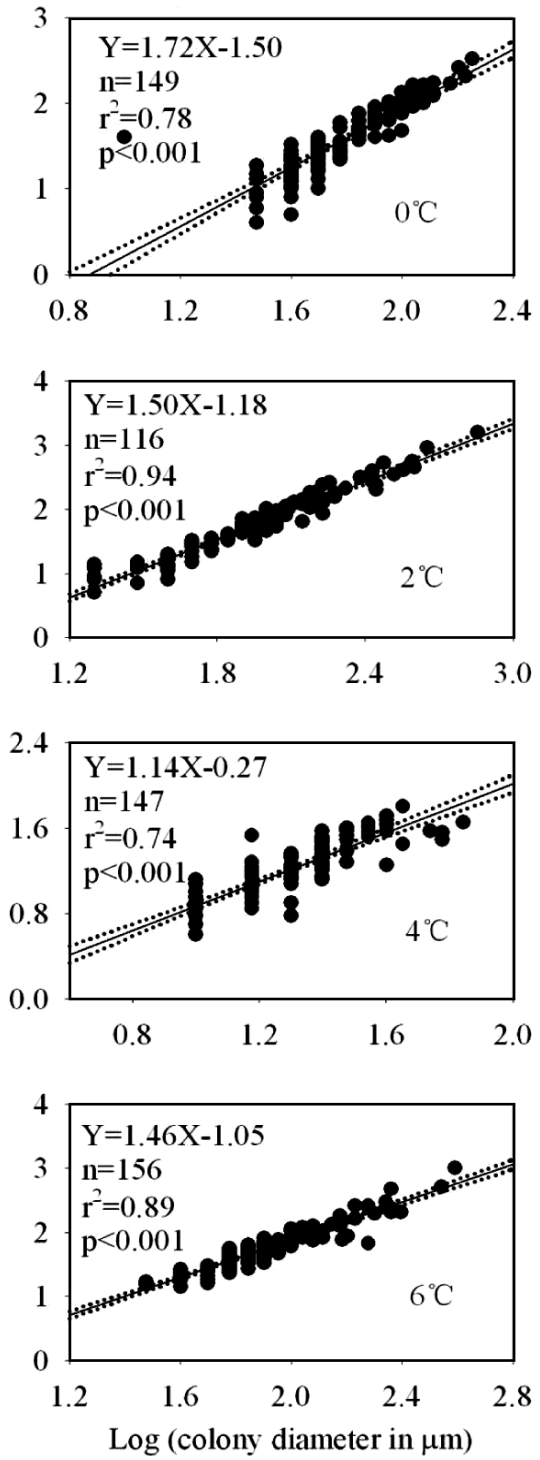

Table 2. Phaeocystis spp. Concentrations (mean $\pm \mathrm{SD}_{i} \mathrm{n}=3$ ) and percentages (mean of triplicates) of total particulate organic carbon ( $\mathrm{POC}_{;}$in $\mu \mathrm{g} \mathrm{C} \mathrm{ml}^{-1}$ ) for solitary cells, colonial cells, and the colonial matrix of Phaeocystis at maximum biomass as a function of temperature $(T)$; NC: no colonies

\begin{tabular}{|c|c|c|c|c|c|c|c|c|}
\hline \multirow[t]{2}{*}{ Species } & \multirow[t]{2}{*}{$T\left({ }^{\circ} \mathrm{C}\right)$} & \multicolumn{2}{|c|}{ Solitary cells } & \multicolumn{2}{|c|}{ Colonial cells } & \multicolumn{2}{|c|}{ Colonial matrix } & \multirow[t]{2}{*}{ Total POC } \\
\hline & & POC & $\%$ & POC & $\%$ & POC & $\%$ & \\
\hline \multirow[t]{5}{*}{ P. globosa } & 16 & $0.08 \pm 0.00$ & $\sim 100$ & 0 & $\sim 0$ & 0 & $\sim 0$ & $0.08 \pm 0.00$ \\
\hline & 20 & $3.23 \pm 0.53$ & 56.7 & $2.00 \pm 0.37$ & 39.8 & $0.47 \pm 0.52$ & 8.2 & $5.70 \pm 0.07$ \\
\hline & 24 & $1.80 \pm 0.11$ & 91.4 & $0.14 \pm 0.01$ & 7.1 & $0.02 \pm 0.00$ & 1.0 & $1.97 \pm 0.13$ \\
\hline & 28 & $13.0 \pm 0.88$ & 100 & $\mathrm{NC}$ & $\mathrm{NC}$ & $\mathrm{NC}$ & $\mathrm{NC}$ & $13.0 \pm 0.88$ \\
\hline & 32 & $8.48 \pm 2.99$ & 100 & $\mathrm{NC}$ & $\mathrm{NC}$ & $\mathrm{NC}$ & $\mathrm{NC}$ & $8.48 \pm 2.99$ \\
\hline \multirow[t]{4}{*}{ P. antarctica } & 0 & $0.04 \pm 0.03$ & 1.9 & $1.74 \pm 0.32$ & 81.7 & $0.35 \pm 0.20$ & 16.4 & $2.13 \pm 0.18$ \\
\hline & 2 & $1.63 \pm 0.70$ & 35.6 & $2.35 \pm 0.69$ & 51.3 & $0.60 \pm 0.15$ & 13.1 & $4.58 \pm 1.54$ \\
\hline & 4 & $0.87 \pm 0.09$ & 24.3 & $1.75 \pm 0.04$ & 48.9 & $0.96 \pm 0.04$ & 26.8 & $3.58 \pm 0.09$ \\
\hline & 6 & $2.57 \pm 0.55$ & 68.0 & $0.96 \pm 0.51$ & 25.4 & $0.25 \pm 0.22$ & 6.6 & $3.78 \pm 0.17$ \\
\hline \multirow[t]{3}{*}{ P. pouchetii } & 4 & $4.54 \pm 1.05$ & 100 & $\mathrm{NC}$ & $\mathrm{NC}$ & $\mathrm{NC}$ & NC & $4.54 \pm 1.05$ \\
\hline & 6 & $9.07 \pm 2.10$ & 100 & $\mathrm{NC}$ & $\mathrm{NC}$ & $\mathrm{NC}$ & $\mathrm{NC}$ & $9.07 \pm 2.10$ \\
\hline & 8 & $13.50 \pm 1.88$ & 100 & $\mathrm{NC}$ & $\mathrm{NC}$ & $\mathrm{NC}$ & $\mathrm{NC}$ & $13.50 \pm 1.88$ \\
\hline
\end{tabular}


growth temperature was lower. However, because in that experiment the phytoplankton was subjected to a sudden change in salinity (31 to $29 \mathrm{psu}$ ) and irradiance (150 to $600 \mu \mathrm{mol} \mathrm{m}{ }^{-2} \mathrm{~s}^{-1}$ ) at the same time, it is difficult to attribute the observations of Peperzak (2003) solely to a temperature effect.

Because we used only 1 Phaeocystis globosa clone in our experiments, extrapolating our results to other strains and environments should be done with caution. Nevertheless, our observations suggest that $P$. globosa (e.g. CCMP 1528) may grow at temperatures warmer than those where it has been observed, although whether it can survive at temperatures above $32^{\circ} \mathrm{C}$ remains to be tested. The $P$. globosa CCMP 1528 strain we used formed colonies regularly at $20^{\circ} \mathrm{C}$, but not at temperatures above $24^{\circ} \mathrm{C}$. This strain may lack the capability of forming colonies at high temperatures, unlike the clone found in the South China Sea. While the ability to form colonies may be influenced by temperature, the growth response appears to be minimally impacted (Fig. 3). On the other hand, lower growth temperature limits for $P$. pouchetii and $P$. antarctica observed in this study differed from previous studies. We found that these 2 coldwater species did not grow at temperatures below 4 and $0^{\circ} \mathrm{C}$, respectively. However, it has been reported that $P$. pouchetii grew at $2^{\circ} \mathrm{C}$ and $P$. antarctica grew at $-2^{\circ} \mathrm{C}$ (Jahnke 1989). In addition, $P$. antarctica is routinely found actively growing at an in situ temperature of $-1.8^{\circ} \mathrm{C}$ (e.g. Smith et al. 2000). The observed differences in growth temperature ranges may also be due to the different strains studied, as well as long-term genetic drift in the cultures.

We found that growth of Phaeocystis globosa occurred over the greatest temperature range among the 3 species tested (over $16^{\circ} \mathrm{C}$ ), which parallels the broad latitudinal distribution of this species (Schoemann et al. 2005). Maximum growth was observed at $20^{\circ} \mathrm{C}$ (Table 1). However, $P$. globosa also exhibited subtle responses to temperature; that is, its maximal biomass, morphology, and photosynthetic potential were all affected by temperature, and these responses were not necessarily coupled to the maximal growth temperature. Indeed, the temperature at which $P$. globosa attained maximal biomass was $28^{\circ} \mathrm{C}$, significantly higher than the temperature for maximum growth rate. This response may partially reflect the carbon partitioning between cells and colonies, but cannot be directly determined from our data.

Phaeocystis species isolated from higher latitudes had narrower temperature tolerances than those at lower latitudes. $P$. antarctica had a narrower growth temperature range $\left(6^{\circ} \mathrm{C}\right)$, which again is not surprising given the narrow in situ range found south of the Antarctic Circumpolar Current. In comparison, $P$. pouchetii grew within the narrowest temperature range in our study (only $4^{\circ} \mathrm{C}$ ), but its physiological responses were relatively insensitive to temperature within this range. Our data suggest that the geographical ranges of $P$. antarctica and $P$. pouchetii are broadly restricted by temperature, whereas the ability of $P$. globosa to bloom in disparate environments may depend more on other factors, such as nutrients, grazing, and irradiance. The highest growth rate for $P$. antarctica was observed at $4^{\circ} \mathrm{C}$ in our experiments, which is higher than the in situ water temperature from -1.86 to $0^{\circ} \mathrm{C}$ at which $P$. antarctica blooms develop in the Ross Sea (Arrigo et al. 1999, van Hilst \& Smith 2002, Shields \& Smith 2008), suggesting that $P$. antarctica growth is more strongly regulated in situ by light and nutrients than by temperature. However, growth of $P$. antarctica during spring may also be a function of its ability to maximize its growth and photosynthesis during periods of low irradiance induced by high solar angles, relatively deep vertical mixing, and the presence of ice (Moisan \& Mitchell 1999, Kropuenske et al. 2009). Its in situ distribution, when compared to its optimal growth temperature, suggests that temperature has a relatively minor role in explaining its appearance in coastal Antarctic systems, but would limit its growth outside the Southern Ocean.

\section{Solitary vs. colonial forms}

Because the different morphotypes of Phaeocystis have very different trophic roles (e.g. Hamm et al. 2001, Smith et al. 2007), temperature-induced changes in cell and carbon partitioning between solitary and colonial forms will inevitably affect many of the ecological processes in systems dominated by Phaeocystis. We found that $P$. globosa reached its highest biomass at $28^{\circ} \mathrm{C}$ but exclusively in solitary form, whereas the colonial form dominated at $20^{\circ} \mathrm{C}$ with maximum growth rate (Table 1). It is noteworthy that for P. globosa and $P$. antarctica colonies, the lowest numbers of cells per unit of colony surface area coincided with the highest growth rates and highest colony abundances. This suggests that at high growth rate, Phaeocystis could build more colonies with fewer cells, which may further reduce grazing mortality (Nejstgaard et al. 2007). Because Phaeocystis solitary cells are more readily consumed by grazers relative to colonies (Nejstgaard et al. 2007), our results suggest that P. globosa might experience increased grazing pressure at higher temperature, and combined with the near-0 sinking rates of solitary cells, could result in a reduced Phaeocystis carbon flux to the sediments (Hamm \& Rousseau 2003, Reigstad \& Wassmann 2007) and increased POC retention within the pelagic food web (Hamm 2000). Reduced colony formation at higher temperature would also reduce the amount of mucilage 
production and bacterial activities that are supported by it (Becquevort et al. 1998, Rousseau et al. 2000).

Growth and temperature-controlled physiological processes were not necessarily tightly coupled. Phaeocystis pouchetii had its maximal growth rate at $8^{\circ} \mathrm{C}$, but did not exhibit significant variations in quantum yield among temperatures, suggesting that photosynthesis and growth were weakly coupled, if at all. In contrast, $P$. antarctica showed maximal growth at $4^{\circ} \mathrm{C}$, but the maximum $F_{\mathrm{v}} / F_{\mathrm{m}}$ was observed at $0^{\circ} \mathrm{C}$. It also had its maximal colonial abundance at the temperature of maximum growth. $F_{\mathrm{v}} / F_{\mathrm{m}}$ values had declined greatly at $6^{\circ} \mathrm{C}$, suggesting that temperature stress was occurring for this species at the highest temperature. Both growth and $F_{\mathrm{v}} / F_{\mathrm{m}}$ declined by approximately $40 \%$ despite their different temperature optima. Thus it appears that photosynthesis and growth are weakly coupled in $P$. antarctica. P. globosa showed a similar response; that is, its $F_{\mathrm{v}} / F_{\mathrm{m}}$ temperature maximum $\left(16^{\circ} \mathrm{C}\right)$ was slightly lower than the maximal growth temperature $\left(20^{\circ} \mathrm{C}\right)$, suggesting weak coupling between photosynthesis and growth. Colony formation and growth were also tightly coupled in this species.

The colonial form of Phaeocystis antarctica was most important at the lowest tested temperature $\left(0^{\circ} \mathrm{C}\right)$, suggesting that low temperatures favored colony formation relative to solitary cells. This may be explained by the higher metabolic demand and the likelihood of nutrient limitation of cellular processes at higher temperatures (Rhee \& Gotham 1981), as colony formation is considered to decrease nutrient uptake by Phaeocystis cells due to the presence of diffusive boundary layers (Ploug et al. 1999). Also, the solitary form of Phaeocystis arguably has diverse nutritional strategies (Verity \& Medlin 2003). This may at least in part explain the lower percentages of colonial cells at relatively high temperatures for both $P$. globosa and $P$. antarctica. Verity et al. (1991) suggested that low temperatures favor $P$. pouchetii colonies, whereas high temperatures favor solitary cells. They further suggested that solitary cells are more efficient in utilizing light for photosynthesis at high temperatures, whereas colonial cells excrete more dissolved organic carbon at increased temperatures, which potentially may reduce their growth. Shields \& Smith (2009) showed that colonial cells had more rapid growth rates than solitary cells, and when coupled with the greater susceptibility to grazing losses (Smith et al. 2000), may explain why colonies form during spring (and at very low temperatures) in the Ross Sea. Mathot et al. (2000) also found that the contribution of colonial cells to total P. antarctica cell abundance was highest in late spring (at the biomass maximum), and that the percentage of solitary cells increased in summer when the sea surface temperature was increasing. While Mathot et al. (2000) suggested that iron limitation in summer resulted in colony senescence and solitary cell liberation, it is possible that elevated temperatures also enhanced the survival and growth of solitary cells as well.

Unlike Phaeocystis globosa CCMP 1528 and $P$. antarctica CCMP 1871 that we used, some strains of Phaeocystis cease forming colonies in culture (e.g. strains of $P$. globosa derived from the South China Sea and the Vietnam coast; Tang et al. 2004). P. pouchetii AJ01 also did not form colonies at all tested temperatures (confirming the results of Malin et al. 1998), suggesting that the role of temperature is minor in controlling the development of colonies. P. pouchetii forms colonies in situ, but the reasons it did not form colonies in culture (like other isolates) remains unclear and independent of temperature. Temperature apparently influenced the growth and abundance of solitary cells, suggesting temperature also would alter the carbon partitioning between solitary cells and colonies in situ in the anticipated warming scenario.

In a Phaeocystis population where solitary cells and colonies coexist, photosynthetically fixed particulate carbon is partitioned among the solitary cells, colonial cells, and the colonial matrix. When only colonies are considered, the ratios of matrix carbon $\left(\mathrm{POC}_{\mathrm{M}}\right.$ ) to colony carbon ranged from 17.5 to $31.3 \%$ for $P$. antarctica and from 6.2 to $16.1 \%$ for P. globosa. The modest (but insignificant) difference in the ratio of matrix carbon to colony carbon among temperatures suggests that the partitioning of POC between colonial cells and the matrix was relatively insensitive to temperature. Our results are quantitatively consistent with the study by Mathot et al. (2000): during a $P$. antarctica bloom in the Ross Sea, matrix carbon represented 10 to $33 \%$ of colony carbon.

\section{Global warming}

Models have predicted that global annual temperature will be elevated by 1.5 to $5.8^{\circ} \mathrm{C}$ by $2070-2100$ (Houghton et al. 2001), which would result in increased sea surface temperature (Bopp et al. 2001), and consequently influence phytoplankton dynamics. Ocean temperature increases have been documented in a number of locations (e.g. Levitus et al. 2000, Hansen et al. 2006, MontesHugo et al. 2009). Our results suggest that rising seawater temperature would directly influence Phaeocystis populations; that is, it would inhibit the growth of $P$. antarctica and $P$. pouchetii, whereas $P$. globosa colonies would become smaller or cease to form. However, the net biomass of $P$. globosa would increase, thus exacerbating some already eutrophic regimes. All of these potential changes would in turn alter the trophic interactions in that specific environment and the regional biogeochemical cycles. 
Acknowledgements. We thank J. Dreyer and C. Freund for technical assistance. This study was supported by the National Natural Science Foundation of China 40606001 (X.W.), China Scholarship Council Scholarships (X.W. and Y.W.), and U.S. National Science Foundation OCE-0850910 (W.O.S. and K.W.T.). This is contribution no. 3098 of the Virginia Institute of Marine Science.

\section{LITERATURE CITED}

Arrigo KR, Robinson DH, Worthen DL, Dunbar RB, DiTullio GR, VanWoert M, Lizotte MP (1999) Phytoplankton community structure and the drawdown of nutrients and $\mathrm{CO}_{2}$ in the Southern Ocean. Science 283:365-367

Baumann MEM, Lancelot C, Brandini FP, Sakshaug E, John DM (1994) The taxonomic identity of the cosmopolitan prymnesiophyte Phaeocystis: a morphological and ecophysiological approach. J Mar Syst 5:5-22

Becquevort S, Rousseau V, Lancelot C (1998) Major and comparable roles for free-living and attached bacteria in the degradation of Phaeocystis-derived organic matter in Belgian coastal waters of the North Sea. Aquat Microb Ecol $14: 39-48$

Bopp L, Monfray P, Aumont O, Dufresne JL and others (2001) Potential impacts of climate change on marine export production. Global Biogeochem Cycles 15:81-99

Brussaard CPD, Marie D, Thyrhaug R, Bratbak G (2001) Flow cytometric analysis of phytoplankton viability following viral infection. Aquat Microb Ecol 26:157-166

Brussaard CPD, Kuipers B, Veldhuis MJW (2005) A mesocosm study of Phaeocystis globosa population dynamics. I. Regulatory role of viruses in bloom control. Harmful Algae 4:859-874

Buma AGJ, Bano N, Veldhuis MJW, Kraay GW (1991) Comparison of the pigmentation of two strains of the prymnesiophyte Phaeocystis sp. Neth J Sea Res 27:173-182

Cadée GC, Hegeman J (2002) Phytoplankton in the Marsdiep at the end of the 20th century: 30 years monitoring biomass, primary production, and Phaeocystis blooms. J Sea Res 48:97-110

Chen YQ, Wang N, Zhang P, Zhou H, Qu LH (2002) Molecular evidence identifies bloom-forming Phaeocystis (Prymensiophyta) from coastal waters of southeast China as Phaeocystis globosa. Biochem Syst Ecol 30:15-22

Elliott DT, Tang KW, Shields AR (2008) Mesozooplankton beneath the summer sea ice in McMurdo Sound, Antarctica: abundance, species composition, and DMSP content. Polar Biol 32:113-122

Gardner WD, Richardson MJ, Smith WO Jr (2000) Seasonal patterns of water column particulate organic carbon and fluxes in the Ross Sea, Antarctica. Deep-Sea Res II 47: 3423-3449

> Gieskes WWC, Leterme SC, Peletier H, Edwards M, Reid PC (2007) Phaeocystis colony distribution in the North Atlantic Ocean since 1948, and interpretation of long-term changes in the Phaetocystis hotspot in the North Sea. Biogeochemistry 83:49-60

Guillard RRL, Ryther JJ (1962) Studies of marine planktonic diatoms. Can J Microbiol 8:229-239

> Hamm CE (2000) Architecture, ecology and biogeochemistry of Phaeocystis colonies. J Sea Res 43:307-315

Hamm CE, Rousseau V (2003) Composition, assimilation and degradation of Phaeocystis globosa-derived fatty acids in the North Sea. J Sea Res 50:271-283

> Hamm CE, Simson DA, Merkel R, Smetacek V (1999) Colonies of Phaeocystis globosa are protected by a thin but tough skin. Mar Ecol Prog Ser 187:101-111

Hamm CE, Reigstad M, Wexels-Riser C, Mülebach A, Wassmann P (2001) On the trophic fate of Phaeocystis pouchetii. VII. Sterols and fatty acids reveal sedimentation of Phaeocystis-derived organic matter via krill fecal strings. Mar Ecol Prog Ser 209:55-69

> Hansen J, Sato M, Ruedy R, Lo K, Lea DW, Medina-Elizalde M (2006) Global temperature change. Proc Natl Acad Sci USA 103:14288-14293

Houghton JT, Ding Y, Griggs DJ, Noguer M and others (eds) (2001) Climate change 2001: the scientific basis. Cambridge University Press, Cambridge

Jahnke J (1989) The light and temperature dependence of growth rate and elemental composition of Phaeocystis globosa Scherffel and P. pouchetii (Har.) Lagerh. in batch cultures. Neth J Sea Res 23:15-21

Jakobsen HH, Tang KW (2002) Effects of protozoan grazing on colony formation in Phaeocystis globosa (Prymnesiophyceae) and the potential costs and benefits. Aquat Microb Ecol 27:261-273

Kropuenske LR, Mills MM, van Dijken GL, Bailey S, Robinson DH, Welschmeyer NA, Arrigo KR (2009) Photophysiology in two major Southern Ocean phytoplankton taxa: photoprotection in Phaeocystis antarctica and Fragilariopsis cylindrus. Limnol Oceanogr 54:1176-1196

Lancelot C, Mathot S (1985) Biochemical fractionation of primary production by phytoplankton in Belgian coastal waters during short- and long-term incubations with ${ }^{14} \mathrm{C}$ bicarbonate. Mar Biol 86:219-226

Lancelot C, Billen G, Sournia A, Weisse T and others (1987) Phaeocystis blooms and nutrient enrichment in the continental coastal zones of the North Sea. Ambio 16:38-46

Lancelot C, Keller MD, Rousseau V, Smith WO Jr, Mathot S (1998) Autoecology of the marine haptophyte Phaeocystis sp. In: Anderson DM, Cembella AD, Hallegraeff GM (eds) Physiological ecology of harmful algal blooms. NATO ASI Series. Springer Verlag, Berlin, p 209-224

Larsen A, Flaten GAF, Sandaa RA, Castberg T and others (2004) Spring phytoplankton bloom dynamics in Norwegian coastal waters: microbial community succession and diversity. Limnol Oceanogr 49:180-190

Levitus S, Antonov JI, Boyer TP, Stephens C (2000) Warming of the world ocean. Science 287:2225-2229

Malin G, Wilson WH, Bratbak G, Liss PS, Mann NH (1998) Elevated production of dimethylsulfide resulting from viral infection of cultures of Phaeocystis pouchetii. Limnol Oceanogr 43:1389-1393

> Mathot S, Smith WO Jr, Carlson CA, Garrison DL, Gowing MM, Vickers CL (2000) Carbon partitioning within Phaeocystis antarctica (Prymnesiophyceae) colonies in the Ross Sea, Antarctica. J Phycol 36:1049-1056

> Medlin L, Zingone A (2007) A taxonomic review of the genus Phaeocystis. Biogeochemistry 83:3-18

Moisan TA, Mitchell BG (1999) Photophysiological acclimation of Phaeocystis antarctica Karsten under light limitation. Limnol Oceanogr 44:247-258

> Montes-Hugo M, Doney SC, Ducklow HW, Fraser W, Martinson D, Stammerjohn SE, Schofield O (2009) Recent changes in phytoplankton communities associated with rapid regional climate change along the western Antarctic Peninsula. Science 323:1470-1473

> Nejstgaard JC, Tang KW, Steinke M, Dutz J, Koski M, Antajan E, Long JE (2007) Zooplankton grazing on Phaeocystis: a quantitative review and future challenges. Biogeochemistry 83:147-172

Parsons TR, Maita Y, Lalli C (1984) A manual of chemical and biological methods for seawater analysis. Pergamon 
Press, Oxford

Peperzak L (2003) Climate change and harmful algal blooms in the North Sea. Acta Oecol 24:S139-S144

Peperzak L, Poelman M (2008) Mass mussel mortality in The Netherlands after a bloom of Phaeocystis globosa (Prymnesiophyceae). J Sea Res 60:220-222

Philippart CJM, Cadée GC, van Raaphorst W, Riegman R (2000) Long-term phytoplankton-nutrient interactions in a shallow coastal sea: algal community structure, nutrient budgets, and denitrification potential. Limnol Oceanogr 45:131-144

Ploug H, Stolte W, Jørgensen BB (1999) Diffusive boundary layers of the colony-forming plankton alga Phaeocystis sp.-implications for nutrient uptake and cellular growth. Limnol Oceanogr 44:1959-1967

Q Qi Y, Chen J, Wang Z, Xu N and others (2004) Some observations on harmful algal bloom (HAB) events along the coast of Guangdong, southern China in 1998. Hydrobiologia 512:209-214

Reigstad M, Wassmann P (2007) Does Phaeocystis spp. contribute significantly to vertical export of biogenic matter? Biogeochemistry 83:217-234

Rhee GY, Gotham IJ (1981) The effect of environmental factors on phytoplankton growth: temperature and the interactions of temperature with nutrient limitation. Limnol Oceanogr 26:635-648

Rousseau V, Vaulot D, Casotti R, Cariou V, Lenz J, Gunkel J, Baumann M (1994) The life cycle of Phaeocystis (Prymnesiophyceae): evidence and hypotheses. J Mar Syst 5:23-39

Rousseau V, Becquevort S, Parent JY, Gasparini S, Daro MH, Tackx M, Lancelot C (2000) Trophic efficiency of the planktonic food web in a coastal ecosystem dominated by Phaeocystis colonies. J Sea Res 43:357-372

Schoemann V, Wollast R, Chou L, Lancelot C (2001) Effects of photosynthesis on the accumulation of $\mathrm{Mn}$ and $\mathrm{Fe}$ by Phaeocystis colonies. Limnol Oceanogr 46:1065-1076

Schoemann V, Becquevort S, Stefels J, Rousseau V, Lancelot C (2005) Phaeocystis blooms in the global ocean and their controlling mechanisms: a review. J Sea Res 53:43-66

Shen P, van Rijssel M, Wang Y, Songhui L, Jufang C, Qi Y (2004) Toxic Phaeocystis globosa strains from China grow at remarkably high temperatures. In: Steidinger KA, Landsberg JH, Tomas CR, Vargo GA (eds) Harmful algae 2002. Florida Fish and Wildlife Conservation Commission, Florida Institute of Oceanography and Intergovernmental Oceanographic Commission of UNESCO, St. Petersburg, FL, p 396-398

Shields AR, Smith WO Jr (2008) An examination of the role of colonial Phaeocystis antarctica in the microbial food web of the Ross Sea. Polar Biol 31:1091-1099

Editorial responsibility: Hans Heinrich Janssen, Oldendorf/Luhe, Germany
Shields AR, Smith WO Jr (2009) Size-fractionated photosynthesis/irradiance relationships during Phaeocystis antarctica-dominated blooms in the Ross Sea, Antarctica. J Plankton Res 31:701-712

Smith WO Jr, Mara J, Hiscock MR, Barber RT (2000) The seasonal cycle of phytoplankton biomass and primary productivity in the Ross Sea, Antarctica. Deep-Sea Res II 47:3119-3140

Smith WO Jr, Ainley DG, Cattaneo-Vietti R (2007) Trophic interactions within the Ross Sea continental shelf ecosystem. Philos Trans R Soc Lond B Biol Sci 362:95-111

Tang DL, Kawamura H, Doan-Nhu H, Takahashi W (2004) Remote sensing oceanography of a harmful algal bloom (HAB) off the coast of southeastern Vietnam. J Geophys Res 109:C03014 doi:10.1029/2003JC002045

Tang KW (2003) Grazing and colony size development in Phaeocystis globosa (Prymnesiophyceae): the role of a chemical signal. J Plankton Res 25:831-842

Tang KW, Smith WO Jr, Elliott DT, Shields AR (2008) Colony size of Phaeocystis antarctica (Prymnesiophyceae) as influenced by zooplankton grazers. J Phycol 44:1372-1378

van Hilst CM, Smith WO Jr (2002) Photosynthesis/irradiance relationships in the Ross Sea, Antarctica, and their control by phytoplankton assemblage composition and environmental factors. Mar Ecol Prog Ser 226:1-12

van Rijssel M, Alderkamp AC, Nejstgaard JC, Sazhin AF, Verity PG (2007) Haemolytic activity of living Phaeocystis pouchetii during mesocosm blooms. Biogeochemistry 83: 189-200

Verity PG, Medlin LK (2003) Observations on colony formation by the cosmopolitan phytoplankton genus Phaeocystis. J Mar Syst 43:153-164

Verity PG, Villareal TA, Smayda TJ (1988) Ecological investigations of blooms of colonial Phaeocystis pouchetii. I. Abundance, biochemical composition, and metabolic rates. J Plankton Res 10:219-248

Verity PG, Smayda TJ, Sakshaug E (1991) Photosynthesis, excretion, and growth rates of Phaeocystis colonies and solitary cells. Polar Res 10:117-128

Vincent WF (1980) Mechanisms of rapid photosynthetic adaptation in natural phytoplankton communities. II. Changes in photochemical capacity as measured by DCMU-induced chlorophyll fluorescence. J Phycol 20: 201-211

Wang Y, Smith WO Jr, Wang XD, Li SS (2010) Subtle biological responses to increased $\mathrm{CO}_{2}$ concentrations by Phaeocystis globosa Scherffel, a harmful algal bloom species. Geophys Res Lett. doi:10.1029/2010GL042666

Zar JH (1984) Biostatistical analysis. 2nd edn, Prentice-Hall, NJ

Submitted: November 25, 2009; Accepted: April 26, 2010

Proofs received from author(s): May 26, 2010 